proof drawn from a series of accurate measurements of time, space, and mass which can be repeated at will, so that the man of science of to-day is inclined by his traditions and training to set aside as unworthy of consideration all phenomena which are incapable of treatment by the methods of precision and logical proof. Experimental psychology, however, that can measure rates of fatigue of memory, or persistence of association, has been received into the fold of orthodox natural science, and is making great progress towards a better comprehension of the workings of the human brain.

But readers of M. Bergson's book, especially those acquainted with "Matter and Memory," will recall that M. Bergson looks upon the human brain merely as a means of obtaining recollection, un organe de rappel, not as the essential phenomenon of human consciousness or of the life of the mind. Thus by the investigations of modern experimental psychology, we learn more about the instrument of communication between the outer and inner worlds-we do not extend our knowledge of those worlds themselves.

M. Bergson suggested that the function of the brain, and indeed of the recognised senses, is to limit rather than to extend the outlook of the mind. They become the organs of attention to life, picking out and preserving ready for use only those impressions and recollections which will be serviceable to the life of the individual or the species. Everything else is masked and put away where, in normal circumstances, it does not distract the attention of the participant from the things which help him to accomplish his mission in the world. But in certain circumstances, such as illness, shock, approaching dissolution of the partnership between mind and body, the limitation may suddenly disappear, the barrier brealss down-perhaps the reason for its existence is removed-and we get produced the phenomena with which the Society for Psychical Research is accustomed to occupy itself, regardless of mathematical theories concerning the nature of proof.

\section{EXPOSURE OF THERMOMETERS FOR THE DETERMINATION OF AIR TEMPERATURE.}

$\Gamma \mathrm{HE}$ report of the Prussian Meteorological Institute for IgI I contains the fourth communication by Prof. G. Hellmann upon the above subject. The observations are discussed at considerable length under three principal heads :--(I) Exposure at a north window (formerly the usual method adopted in Germany) and in a Stevenson screen in a meadow (or field) at Potsdam. This section is accompanied by an interesting set of monthly diagrams showing the mean daily range due to both exposures. (2) Comparison of the Stevenson screen with the aspiration thermometer at Potsdam and Grünberg, in Silesia. (3) Comparison of the true air temperature in a meadow and in the north shade of Potsdam Observatory (about half a metre from the wall).

The following shortened summary gives some of the chief results deduced from the four communications :-

(1) The determination of the temperature near the north wall of a building is practically independent of the nature of the window exposure; the thermometer may even be hung freely, so long as it is not exposed to direct or indirect radiation.

(2) An aspiration thermometer installed near the north wall of a building gives results agreeing very closely with those of the usual window exposure; in the summer half-year the latter gives $0 \cdot I^{\circ}-0 \cdot 2^{\circ}$ (C.) higher readings in the afternoon, while in the winter season the morning and evening observation hours give rather too low readings.

(3) A freely exposed Stevenson screen gives in North Germany too high readings at the afternoon observation throughout the year to the extent of $0^{\circ} I^{\circ}-0^{\circ} 2^{\circ}$ in winter, and $0^{\circ} 2^{\circ}-0^{\circ} 4^{\circ}$ in summer. At the evening. reading also it is $0^{\circ} 1^{\circ}-0^{\circ} 2^{\circ}$ too high in summer, and $\mathrm{O}^{\circ} \mathrm{I}^{\circ}$ too low in the other seasons; at other hours the differences are very small and of varying sign.

(4) The errors of this screen differ in different climates and with varying conditions of weather.

(5) The true temperature in the shade, on the north side of a building, both as regards absolute amount and daily period, is quite different from that obtained in an open field. At the $2 \mathrm{~h}$. p.m. reading the excess of temperature in the field is $0^{\circ} \mathrm{I}^{\circ}$ in December and $\mathrm{r}^{\circ} \mathrm{O}^{\circ}$ in July. These differences increase with duration and intensity of sunshine, and decrease with strong winds.

(6) The true daily means in the north shade of a building and in a meadow differ but little from each other; in winter the meadow daily mean is $0^{\circ} 1^{\circ}-0^{\circ} 3^{\circ}$ the lower of the two.

(7) The hourly readings in the two positions are not comparable, but the daily means derived from the hours $7,2,9$ by Kämtz's formula exhibit relatively small differences.

(8) The daily oscillation of temperature near the house is about $0^{\circ} 3^{\circ}$ in December to $r 6^{\circ}$ in June less than in the meadow.

(9) The daily maximum is from $0^{\circ} \mathrm{I}$ hour in December to $0^{\circ} 9$ hour in June later in the shade of the house than in the meadow, but the time of the occurrence of the minimum is the same in both positions.

\section{HYDROGRAPHY IN ITALY.1}

$T H E$ third annual report on the activities of the Italian Hydrographic Department deals with the year IgII, a period which is stated to have been of particular importance in its history, on account of certain drastic changes which were brought about in the administration of the service, through the passing of a law for the better regulation of the work of collecting and classifying data relating to rivers and their mountain basins, to lagoons and to the sea, and for the systematic study of all streams, their sources and outlets.

This new law assigned to the hydrographic service, in addition to the director, four specialist assistants, and has rendered possible the subdivision of the department into four sections, distinguished as fluvialhydrographical, maritime-hydrographical, meteorological, and geological.

The report deals with the present and proposed fields of operations, and enumerates the various subservices to be undertaken. These are as follows :(a) Meteorological; (b) aërological; (c) telegraphic, for forecasting the weather; (d) meteorological, for the city of Venice; $(e)$ midday signalling for the port of Venice; $(f)$ pluviometric; $(g)$ nivometric; $(h)$ hydrometric; $(i)$ stream measurement; $(l)$ flood prediction; $(m)$ levelling observations; $(n)$ maregraphic; $(o)$ maregraphic for the city of Venice; and $(p)$ maritime lagoon reclamation. Of these services $(b),(d),(e)$, and $(g)$ were only inaugurated in 1912 .

Within the limits of a brief notice it is not possible to do more than thus indicate in very general terms the extent of ground covered by the report, and those who desire fuller information or who are interested in any way in the extension and development of hydro-

I "Terza Relazione Annuale del Direttore dell' Ufficio Idrografico." By Giovanni Magrini. Pp. $7 \mathrm{t}$ tplates tmaps. (Venice : Carlo Ferrari, IyI2.)

NO. 2275 , VOL. 9I] 